\title{
Paleoproductivity, ventilation, and organic carbon burial in the Santa Barbara Basin (ODP Site 893, off California) since the last glacial
}

\author{
Alexandra J. Nederbragt, ${ }^{1}$ Jürgen W. Thurow, ${ }^{1}$ and Paul R. Bown ${ }^{1}$ \\ Received 21 May 2007; revised 9 September 2007; accepted 6 November 2007; published 27 February 2008.
}

[1] Biogenic burial rates and coccolith assemblage data were generated for the past 16 ka at ODP Site 893 in the Santa Barbara Basin, off California, to determine if dysoxic events in the basin were related to changes in marine productivity. Coccolith abundance data show that changes in surface water conditions did indeed change in concert with oxygen levels at the sea floor. However, organic carbon burial rates varied independently, indicating that oxygenation of the water column is related mainly to intermediate water ventilation. A strong correlation of organic carbon burial rates with lithogenic, and to a lesser extent with carbonate and opal accumulation rates confirms recent conclusions that the export of organic carbon from the sea surface is largely controlled by the presence of ballast minerals.

Citation: Nederbragt, A. J., J. W. Thurow, and P. R. Bown (2008), Paleoproductivity, ventilation, and organic carbon burial in the Santa Barbara Basin (ODP Site 893, off California) since the last glacial, Paleoceanography, 23, PA1211, doi:10.1029/2007PA001501.

\section{Introduction}

[2] The ocean's "biological pump" (i.e., the export of organic carbon from the surface water to the ocean floor) plays a major role in the global carbon cycle by modulating atmospheric $\mathrm{CO}_{2}$ concentrations [Berner and Raiswell, 1983; Broecker, 1982; Ittekkot, 1993; Sigman and Boyle, 2000]. A substantial part of the carbon export is concentrated in high-productivity areas along continental margins. Ocean margin areas support $10-15 \%$ of total oceanic chlorophyll production but may account for $>40 \%$ of the global export of marine organic carbon to the seafloor [Muller-Karger et al., 2005]. At the same time, ocean margins are an important sink for nutrients, thereby modulating the long-term nutrient availability. High rates of phosphogenesis occur predominantly in marginal seas and under high-productivity regions in the ocean [Filippelli and Delaney, 1996], while highproductivity upwelling regions in the eastern Pacific and Arabian Sea are the main sites where denitrification occurs within the oxygen minimum zone (OMZ) [Ganeshram et al., 2000].

[3] Reconstructing the history of paleoproductivity in high-productivity areas is therefore important to understand how climate change affects the global carbon cycle over longer periods of time. However, process studies in the modern oceans have shown that the link between surface water productivity and the resulting rates of carbon burial is modified by various processes within the water column and at the sediment-water interface. Sediment trap data for the open ocean show that the UK.

${ }^{1}$ Department of Earth Sciences, University College London, London, carbon export efficiency from the surface water is largely controlled by the presence of ballast minerals [Armstrong et al., 2002; Francois et al., 2002; Ittekkot, 1993; Klaas and Archer, 2002; McCave, 1975]. The presence/absence of oxygen in the sediment is thought traditionally to have an effect on the preservation of organic matter, but the importance is heavily debated [Calvert, 1987; Devol and Hartnett, 2001; Ganeshram et al., 1999; Hedges et al., 2001; Nederbragt et al., 2004]. There is a strong correlation between organic carbon burial rates at the modern sea floor and bulk sedimentation rates, which is attributed to better preservation due to shortening of oxygen exposure times [Hedges et al., 2001; Müller and Suess, 1979].

[4] It remains difficult to quantify the effect of processes in the modern ocean on long-term variation in carbon burial rates. One of the factors is the difference in scale between short instrumental records with strong interannual variability and the long-term average accumulation rates that can be reconstructed in most sediment cores. Such a gap in temporal resolution can be bridged through analysis of annually laminated (varved) marine sediments, which allow paleoflux rates to be estimated at down to annual resolution over long periods of time.

[5] The Santa Barbara Basin, off California, (Figure 1) is one of a number of marine basins that offers such a varved record. The sediment record in the basin provides a sensitive recorder of global and regional climate change at short (interannual to decadal) and long (millennial to glacial/ interglacial) timescales [Behl and Kennett, 1996; Biondi et al., 1997; Cannariato and Kennett, 1999; Hendy et al., 2002; Kennett et al., 2000; Nederbragt and Thurow, 2005b; Schimmelmann and Kastner, 1993; Soutar and Crill, 1977]. Here we compare sedimentation rate dependent and independent paleoproductivity proxies to unravel the upwelling and ventilation history of the Santa Barbara Basin since the 


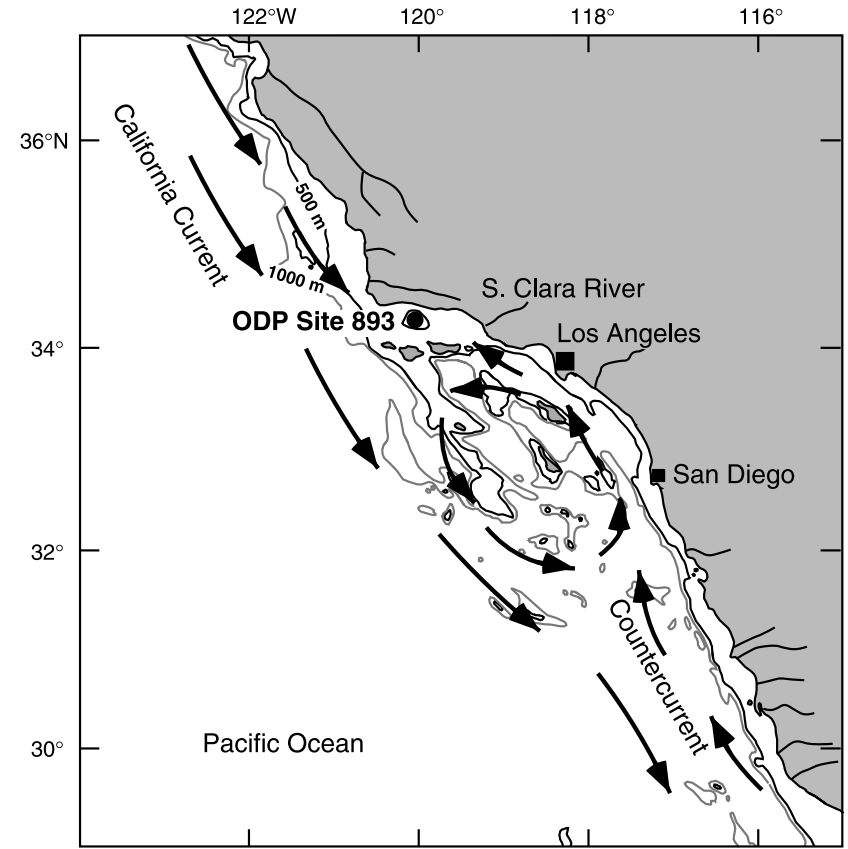

Figure 1. Map showing surface water currents along the California margin, main rivers draining into the Pacific Ocean, and location of ODP Site 893 in the Santa Barbara Basin.

last glacial, to reconstruct how rates of organic carbon burial are influenced by climate change.

\section{Paleoceanographic Setting}

[6] The Santa Barbara Basin is silled at a depth of $450 \mathrm{~m}$ (Figure 1), and waters in the center of the basin below the sill are dysoxic. The dysoxia is the result of slow deep water renewal rates and high oxygen demand due to high surface water productivity [Reimers et al., 1990]. There is a strong seasonal cycle, with coastal upwelling during spring and early summer and increased rainfall and riverine runoff during winter [Lange et al., 2000; Soutar and Crill, 1977; Thunell et al., 1995]. Sediments in the center of the basin are hemipelagic and varved, consisting of alternating light, diatom-rich summer laminae and dark, terrigenous winter laminae [Soutar and Crill, 1977].

[7] Most of the lithogenic material in the Santa Barbara Basin is derived from the Santa Clara River, which drains into the eastern part of the basin (Figure 1) [Fleischner, 1972]. During periods of rainfall, surface water plumes of suspended riverine material are transported westward into the center of the Santa Barbara Basin. The plumes are held by local gyres and last for days to a few weeks [Gorsline et al., 1984; Thornton, 1984]. Further suspended lithogenic material is produced through wave and current winnowing of fine-grained sediments deposited on the shelf near the Santa Clara River. Major river floods and/ or tectonically induced submarine slope failures periodically cause turbidity currents along the sea floor of the Santa Barbara Basin. However, they result in discrete deposits that interrupt the normal hemipelagic varved sediments [Thornton, 1984].

[8] The main surface water currents in the region are the equatorward flowing California Current and the poleward flowing California Counter Current (Figure 1). Coastal upwelling during spring is associated with intensification of the California Current near-shore when northerly winds predominate. The main current south of the Santa Barbara Basin is the warmer, northerly flowing California Counter Current, which enters the eastern part of Santa Barbara Basin throughout the year except in spring [Harms and Winant, 1998]. Minimum sea surface temperature (SST) values are found in the Santa Barbara Basin during the upwelling season with values around $12-13^{\circ} \mathrm{C}$ [Thunell, 1998a; Thunell et al., 1995]. In late summer and autumn the water column becomes thermally stratified, with SST values $>16^{\circ} \mathrm{C}$.

[9] The subsurface water column is influenced by two intermediate water masses, both with low preformed oxygen content. North Pacific Intermediate Water (NIPW) flows southward at depths between 300 and $700 \mathrm{~m}$ [Talley, 1993]. The shallower and northward flowing California Undercurrent is derived from the equatorial Pacific, where high equatorial productivity induces dysoxic conditions in the very shallow subsurface [Hickey, 1998]. Deep water renewal in the Santa Barbara Basin is associated with a strong California Current and occurs during the upwelling season when NIPW spills over the deep sill in the west to enter the basin [Reimers et al., 1990].

[10] Conditions throughout the water column in the Santa Barbara Basin have varied over the past 60,000 years in close correlation with Northern Hemisphere climate as registered in the GISP2 $\delta^{18} \mathrm{O}$ record. Warm periods (Holocene, Bölling/Allerød, and stadial events during Marine Isotope Stage (MIS) 3) are characterized by decreased ventilation of water below sill depth and deposition of laminated sediments [Behl and Kennett, 1996]. Simultaneous warming of the surface waters is indicated by planktonic foraminiferal $\delta^{18} \mathrm{O}$ values [Hendy and Kennett, 1999; Kennett et al., 2000]. The correlation with global climate is not limited to large climate excursions. For example, small amplitude changes in the GISP2 $\delta^{18} \mathrm{O}$ record are reflected in changes in sediment composition during the Last Glacial Maximum [Hendy et al., 2002] and the Holocene [Nederbragt and Thurow, 2005b].

\section{Material and Methods}

[11] ODP Site 893 is located in the centre of the Santa Barbara Basin at a water depth of $577 \mathrm{~m}$ (Figure 1). A latest Quaternary record was retrieved in two parallel holes, with the base of the Bölling/Allerød at 24 mbsf. Holocene and Bölling/Allerød sediments are predominantly varved, while the Younger Dryas and MIS 2 sediments are homogeneous [Behl and Kennett, 1996; Nederbragt and Thurow, 2005b]. At the time that the cores were collected it was not recognized that substantial gaps occur between consecutive cores from a single hole, presumably due to expansion of the sediment during retrieval of the core. A splice was therefore constructed for Holes 893A and 893B down to $27 \mathrm{mcd}$ 


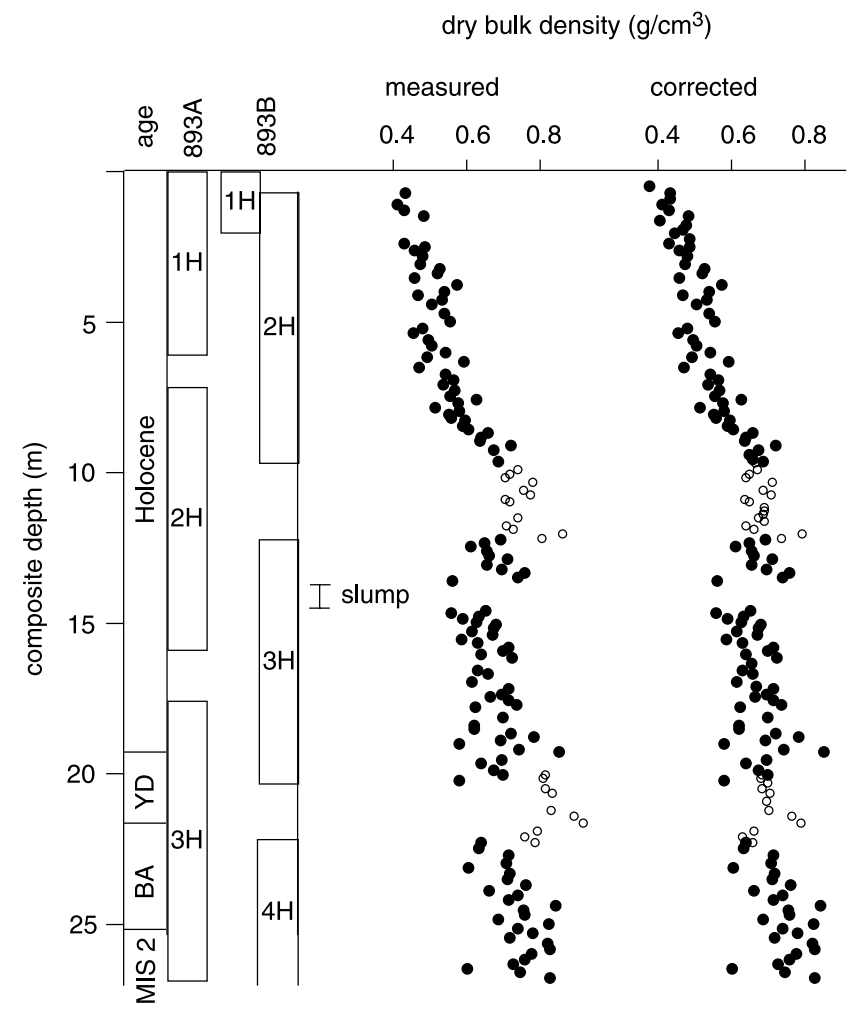

Figure 2. Composite section for ODP Holes 893A and 893B against void corrected depth (after Nederbragt and Thurow [2005b]) with raw and corrected dry bulk density values for Hole 893A (open circles) and 893B (solid circles). YD: Younger Dryas; BA: Bölling/Allerød; and MIS: Marine Isotope Stage. See section 3 for description of sediment density estimation.

(Figure 2) to obtain a continuous and complete stratigraphic record for the past $\sim 16,000$ years [Nederbragt and Thurow, 2005b]. The age model for the Holocene and Bölling/ Allerød is based on varve measurements with interpolation across homogeneous intervals; turbidites and flood layers were subtracted from the sequence. An average linear sedimentation rate was estimated for the Younger Dryas using the thickness of the bioturbated interval divided by the length of the Younger Dryas as measured in the GISP2 ice core (1300 years; Nederbragt and Thurow [2005b]). Sedimentation rates for MIS 2 sediments are estimated from radiocarbon ages presented by Hendy et al. [2002].

[12] Samples were collected in 2002, 10 years after the cores were taken. Our samples are mainly from Hole 893B, which was largely unsampled at the time, to be able to obtain samples with a known volume. Samples were taken from Hole 893A, which was already extensively sampled, only where necessary to fill in gaps between cores in the B-hole (Figure 2). Sample spacing was calculated from the age model to obtain a sample approximately every 100 years. Each sample represents an average of a 5-10 year time interval. For practical reasons samples were taken with $5 \mathrm{cc}$ sample plugs. The resolution of published dry bulk density (DBD) measurements [Kennett et al., 1994] was too low for the purpose of this paper. We therefore estimated DBD for all samples to obtain an internally consistent set of data even though the age of the cores and sample size were not well suited for this purpose. The length of the retrieved sample was measured, from which the sediment volume was calculated. All samples were weighed when still wet, dried overnight at $40^{\circ} \mathrm{C}$, and weighed again, to estimate water content. Dry bulk density (DBD) is estimated by multiplying the dry weight with the sample volume after correction for salt content. For 19 out of 165 samples it was not possible to control the sample volume, either because the sediment was too wet to retrieve a coherent sample (top few meters in Hole $893 \mathrm{~B}$ ) or because the core surface was too heavily sampled to completely fill the sample plug (Hole 893A). For these samples, DBD was estimated from their composition and water content following Gardner et al. [1997]. However, the water content of samples from Hole 893A was consistently lower than in surrounding samples in Hole 893B, resulting in higher DBD estimates (Figure 2). Apparently, sediments in the heavily sampled 893A cores had dried out more rapidly during storage than the almost intact $893 \mathrm{~B}$ cores. The Hole 893A DBD estimates were therefore shifted by a constant value to obtain the best match with overlapping values in Hole 893B (Figure 2).

[13] Total organic carbon (TOC), carbonate, and opal content have been published by Nederbragt et al. [2006]. Lithogenic content was estimated indirectly by subtracting the sum of the biogenic components. In addition, percentages of the biogenic components were calculated relative to each other on a lithogenic-free basis. Burial rates of all components were estimated by multiplying the percentage data with DBD values and linear sedimentation rates. Varve thickness measurements of Nederbragt and Thurow [2005b] were integrated to obtain the average sedimentation rate for each sample interval. A lamination index was calculated for a $4 \mathrm{~cm}$ interval centered around each of the samples used in this study. Values range from 1 for continuously varved to 0 for homogeneous sediments [Nederbragt and Thurow, 2005b].

[14] Coccolith abundance data were generated from standard smear slides using a light microscope in crosspolarized light at $1000 \times$ magnification. Because of high sand/silt content of part of the sediments, samples were disaggregated for $10 \mathrm{sec}$ in an ultrasonic bath in $50 \mathrm{ml}$ of water, after which the suspension was allowed to rest for $10 \mathrm{sec}$ to allow sand and coarse silt grains to settle. A few drops of the remaining suspended material were then pipetted onto a cover slip, and distributed as evenly as possible. Species percentage data are calculated from counts of 200 specimens for all species present, after which a further 80 100 fields of view were scanned counting rare species only. Coccoliths of extinct species were counted to estimate the degree of reworking. Modern species concepts mostly conform to Young et al. [2003]. Amongst the Gephyrocapsa species, only G. oceanica was counted separately, i.e., forms usually $>4 \mu \mathrm{m}$ with a high-angle bridge [McIntyre et al., 1970]. Amongst remaining Gephyrocapsa specimens a distinction was made visually on the basis of size, between specimens $>\sim 2.7 \mu \mathrm{m}$ (G. mullerae s.1.) and $<\sim 2.7 \mu \mathrm{m}$ 


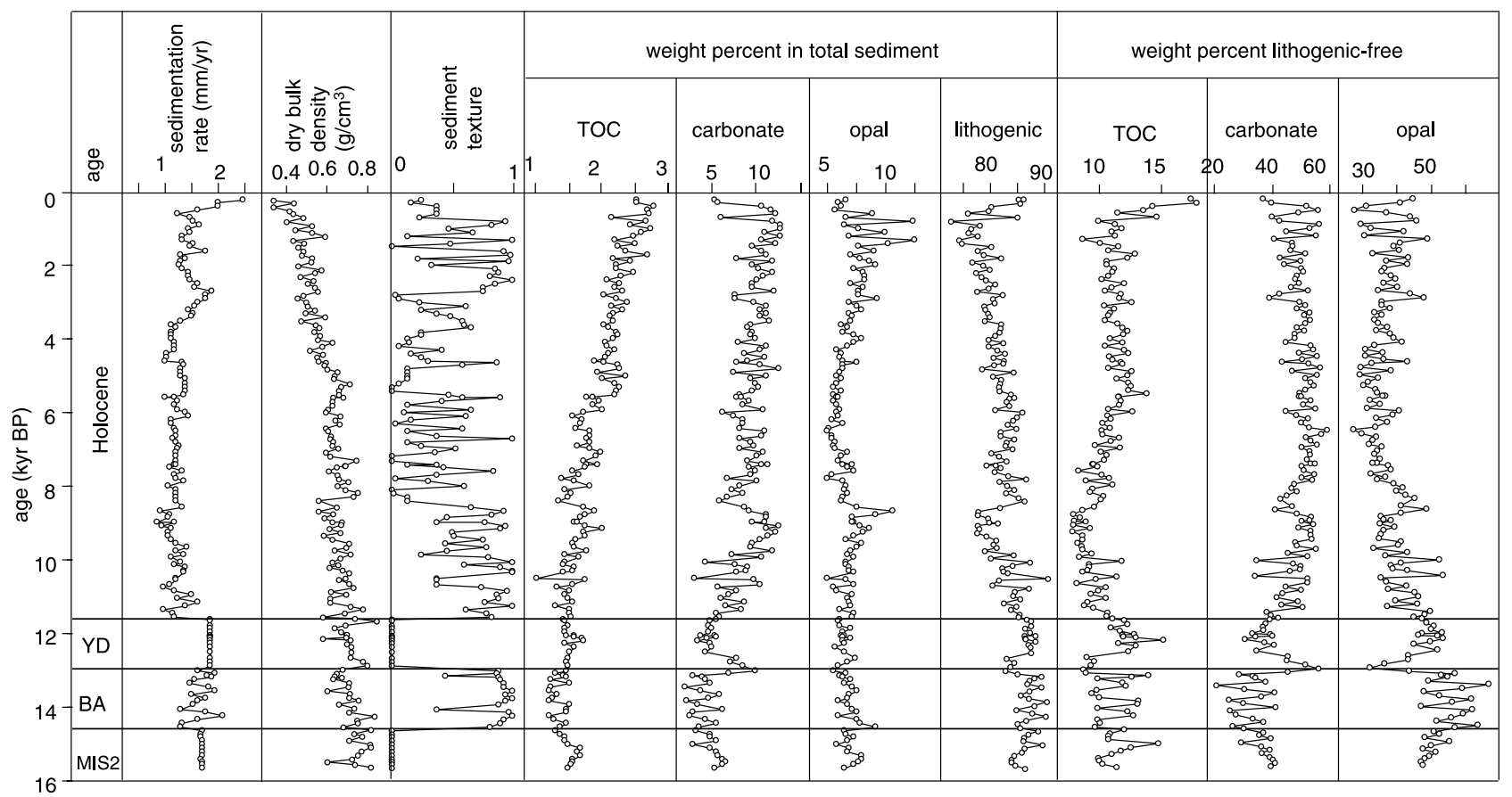

Figure 3. Plots of sedimentation rates, dry bulk density (DBD), sediment texture, and the main sediment components against age. Sediment texture ranges from $0=$ homogeneous to $1=$ continuously varved (after Nederbragt and Thurow [2005b]).

(small Gephyrocapsa), but for data analysis purposes the two are grouped because of potential lack of consistency. A more consistent distinction would require a biometric approach, but the visual estimates did not suggest that this would produce more meaningful results.

[15] Interpretation of environmental conditions from coccolithophid assemblages is based on the seasonal distribution found in sediment trap experiments in upwelling regions, not only in the Santa Barbara Basin [De Bernardi et al., 2005] but also in the San Pedro Basin, the Gulf of California [Ziveri and Thunell, 2000; Ziveri et al., 1995], and the Indian Ocean, off Somalia, [Broerse et al., 2000]. In all sediment trap experiments Florisphaera profunda was found to be the most abundant at times that the water column was stratified [Broerse et al., 2000; De Bernardi et al., 2005; Ziveri and Thunell, 2000; Ziveri et al., 1995]. This species has a preference for low light and low nutrient conditions in a deep thermocline, and can be used as an indicator for the presence of a deep chlorophyll maximum [Molfino and McIntyre, 1990; Ziveri et al., 1995]. However, the geographic range of $F$. profunda is restricted to tropical and subtropical water masses [Okada and McIntyre, 1977]. High fluxes as well as high percentages of Helicospaera carteri and Calcidiscus leptoporus correlate with high coccolith production, which occurs before or after peak upwelling conditions [Broerse et al., 2000; Ziveri and Thunell, 2000; Ziveri et al., 1995]. Gephyrocapsa oceanica is a tropical to subtropical opportunistic species [Okada and McIntyre, 1979], which shows an increase in abundance during the upwelling season [Broerse et al., 2000; De Bernardi et al., 2005; Ziveri et al., 1995]. Two further morphotypes encountered at Site 893 have clear ecological preferences. Umbilicosphaera sibogae is known to be limited to warm, oligotrophic waters [Okada and McIntyre, 1977]. On the other hand Coccolithus pelagicus subsp. pelagicus is an indicator for cold water influences [Geisen et al., 2002; Narciso et al., 2006].

[16] Blackman-Tukey power and coherence spectra were estimated for pairs of variables using the time series package Analyseries [Paillard et al., 1996]. Spectra are calculated for the last $11.5 \mathrm{ka}$ only, during which time span all records are more or less stationary. High-amplitude fluctuations in sediment texture and in coccolith assemblage composition across the MIS 2, Bölling/Allerød, Younger Dryas, and Holocene transitions would dominate the power spectra when included and obscure the lower-amplitude fluctuations within the Holocene. Background red noise spectra are estimated as the best fit straight line through the log-log transform of each power spectrum.

\section{Results}

\subsection{Sediment Composition and Burial Rates}

[17] There are distinct changes in sediment texture at Site 893 but the shifts between laminated and homogeneous sediments are not reflected in a noticeable change in sediment composition (Figure 3). All sediment components show gradual long-term trends with relatively weakly developed short-term fluctuations. Within the bulk sediment, TOC and carbonate content both increase gradually from the base of the section toward the top, while lithogenic content decreases slightly over the same interval (Figure 3). Opal content shows two maxima within the Holocene but 


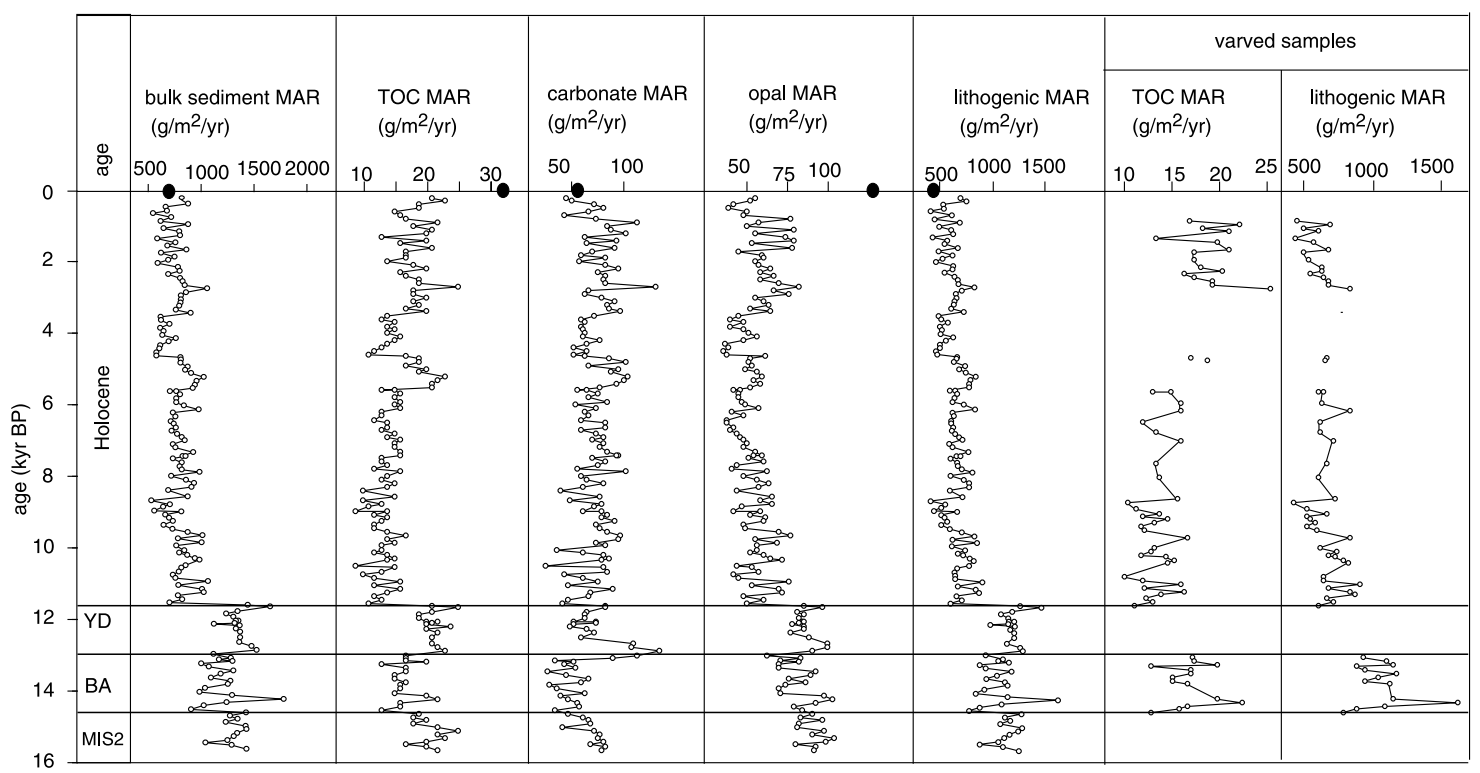

Figure 4. Mass accumulation rates of lithogenic and biogenic components. Solid circles at $0 \mathrm{ka}$ represent sediment trap fluxes in the Santa Barbara Basin from 1993-1996 at $50 \mathrm{~m}$ above the seafloor [Thunell, 1998a]. Note similarity of all burial rates with sedimentation rates in Figure 3 . TOC and lithogenic accumulation rates are also shown for entirely varved samples only to illustrate that the correlation with sedimentation rates is real.

otherwise remains essentially constant throughout the section. On a lithogenic free basis, the biogenic components show a broad, weakly developed maximum in TOC and carbonate content relative to opal within the middle part of the Holocene between $\sim 7$ and $\sim 3$ ka BP. A striking feature is a close visual correlation of short-term fluctuations in lithogenic-free TOC content with the total percentage of lithogenic material (Figure 3). That is, the contribution of TOC increases relative to the other biogenic components when the lithogenic content is high.

[18] Burial rates of all sediment components show more pronounced millennial variability than the percentage data (Figure 4). Within the Holocene there is a strong correlation between all components (Figure 4), with millennial fluctuations that are similar to those in sedimentation rates (Figure 3). Of the terms in the burial rate equation (sedimentation rate, dry bulk density, and weight percent of the components) sedimentation rates show gradual variation at the millennial scale, while more rapid fluctuations are subdued. In contrast, dry bulk density and the weight percentage data are much more variable at the centennial scale. Sedimentation rates therefore have a strong influence on millennial variability in the burial rates of lithogenic and biogenic components during the Holocene. However, the correlation with sedimentation rates is a real feature and not the result of interpolation of sedimentation rates within bioturbated intervals. The same relation is seen in entirely varved samples, for which the sedimentation rate is measured directly from the thickness of annual couplets (Figure 4). The linear correlation between TOC and lithogenic burial rates for varved samples exclusively is $\mathrm{r}=0.83(\mathrm{n}=16)$ in the upper Holocene and $r=0.74(n=62)$ in the lower Holocene.

[19] Within the lower part of the section there is a shortlasting increase in carbonate accumulation across the Bölling/Allerød-Younger Dryas transition, which is probably related to a nonpelagic source of carbonate. In this interval, there is no corresponding increase in coccolith abundance (Figure 5) nor in planktonic foraminiferal accumulation [Hendy et al., 2002]. Otherwise, changes in burial fluxes across the MIS 2-Bölling/Allerød-Younger Dryas transitions are modest except for organic carbon.

[20] Estimates for carbon burial rates show an increase during MIS 2 and the Younger Dryas compared to the Bölling/Allerød and Holocene (Figure 4). The apparent decrease in carbon burial from MIS 2 into the Bölling/ Allerød is $19 \%$ (Figure 4), which is well within the error of the radiocarbon based age model for the upper part of the glacial sequence [Hendy et al., 2002]. However, the estimates for higher than average carbon burial rates during the Younger Dryas are more reliable. Average carbon burial rates during the Younger Dryas are 28\% and 60\% higher than the average for the Bölling/Allerød and the lower part of the Holocene respectively (Figure 4). Especially the difference with the lower Holocene is too large to be attributed entirely to an error in the age model. It would require that the bioturbated interval represents a time interval that is $60 \%$ longer than the 1300 years assigned, or 2080 years in total, an offset that is beyond the error on both radiocarbon and varve based age models for Site 893 [Hendy et al., 2002; Nederbragt and Thurow, 2005b]. However, whether the decrease not only in organic carbon but in all other burial rates at end of the Younger Dryas was 


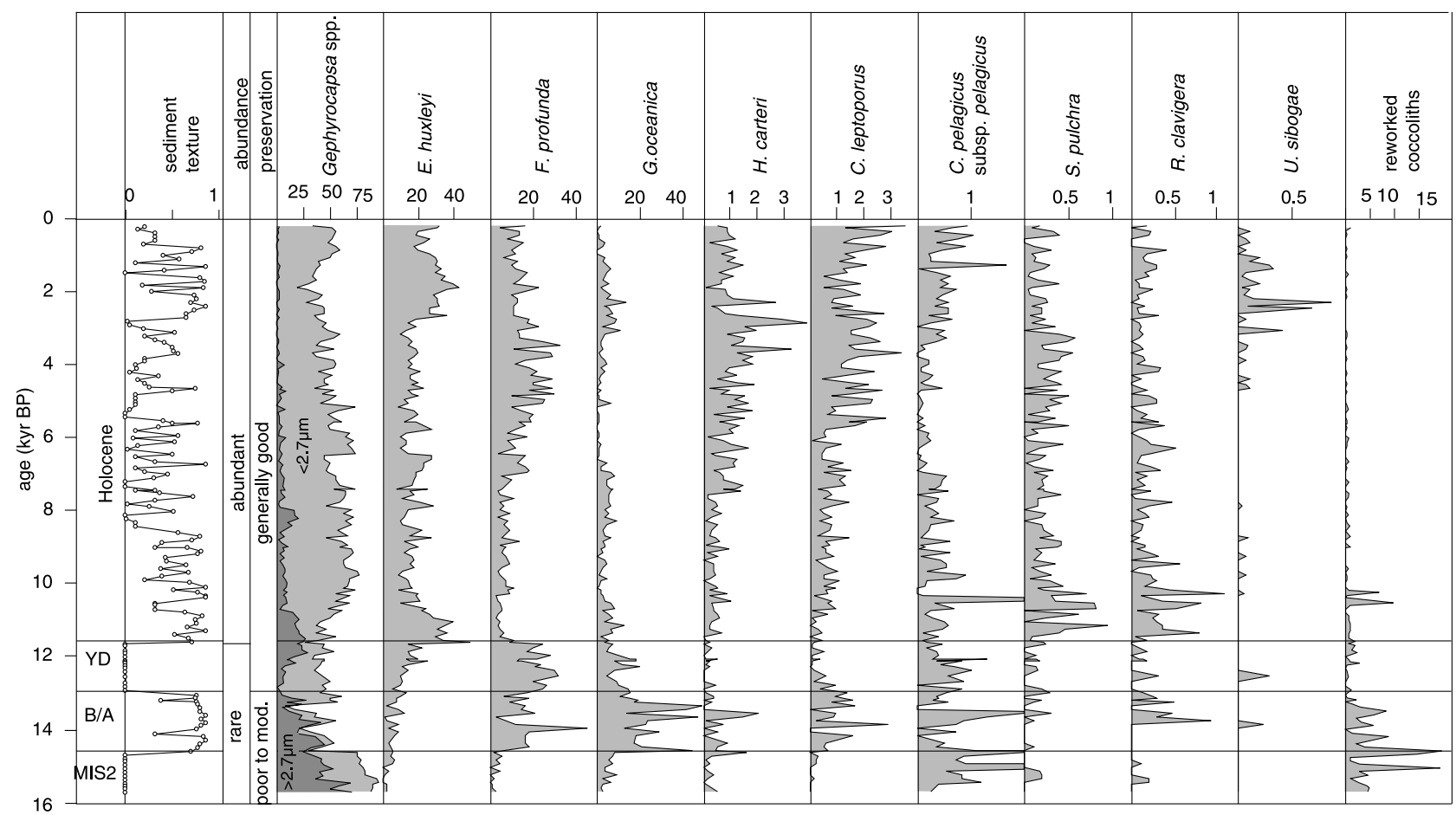

Figure 5. Percentage distribution data of selected coccolith species compared to sediment texture.

indeed as abrupt as suggested by the estimates is less certain (Figure 4). The abruptness of the change is virtually entirely due to the shift from long-term interpolation of sedimentation rates within the Younger Dryas to varve-based measurements within the Holocene, as the percentage data and DBD values remain unchanged (Figure 3). The actual variation in burial rates at the end of the Younger Dryas may well have been more gradual.

\subsection{Coccolith Assemblage Distribution}

[21] Coccolith preservation is poor to moderate in the lower part of the section in MIS 2 and Bölling/Allerød sediments, but generally good in younger sediments including the Younger Dryas. The abundance is low until the end of the Younger Dryas (Figure 5), which corresponds to the interval with low carbonate content (Figure 3). The number of specimens per field of view is much higher in all Holocene samples, which reflects higher carbonate content in combination with an increase in abundance of small coccoliths (Emiliania huxleyi and small Gephyrocapsa). Reworked specimens are common in the lower part of the section but decrease in abundance until they are rare after $\sim 10 \mathrm{ka}$ BP. Nannofossil assemblages in the section as a whole are dominated by E. huxleyi, Gephyrocapsa spp., and F. profunda in variable proportions to each other (Figure 5). Of all other species, only $H$. carteri, C. leptoporus, and C. pelagicus form consistently more than $1 \%$ of the flora at least in part of the section. Part of $C$. pelagicus probably represent reworked Tertiary specimens, as the highest frequencies of this species occur in samples with noticeable amounts of reworked nannofossils. In samples without reworking, $C$. pelagicus liths are invariably small
$(<10 \mu \mathrm{m})$, representing the cold water subspecies $C$. pelagicus subsp. pelagicus [Geisen et al., 2002]. Remaining species that are present in the samples are not shown, as they are too rare $(<0.5 \%)$ to show a consistent distribution pattern. The exception is $U$. sibogae (Figure 5), which is a good indicator for oligotrophic conditions [Okada and McIntyre, 1977].

[22] Coccolith census counts show that there were pronounced changes in assemblage composition across millennial climate transitions (Figure 5), in contrast to the lack of change in sediment composition. Glacial floras consist for more than $80 \%$ of Gephyrocapsa spp., of which $G$. oceanica and small placoliths are a minor constituent. All other species are rare compared to values that they obtain in younger sediments, with the exception of $C$. pelagicus. Between the last sample in the bioturbated glacial sediments and the first sample within the laminated Bölling/Allerød there is a sudden increase in the abundance of $G$. oceanica and $F$. profunda. Amongst the rare species, $C$. leptoporus shows an increase in abundance while $C$. pelagicus decreases. Given the sample resolution there is at most a lead or lag of $\sim 50$ years between the change in coccolith assemblages and sediment texture. Preservation within the Bölling/Allerød is generally poor, with one sample out of 18 that is essentially barren, while three more showed less than one specimen per field of view. The large fluctuations in species composition (Figure 5) within this interval may therefore reflect preferential preservation. The transition into the Younger Dryas is marked by a relatively gradual change in coccolith assemblage composition, with a further increase in abundance of $F$. profunda but also a general decrease 

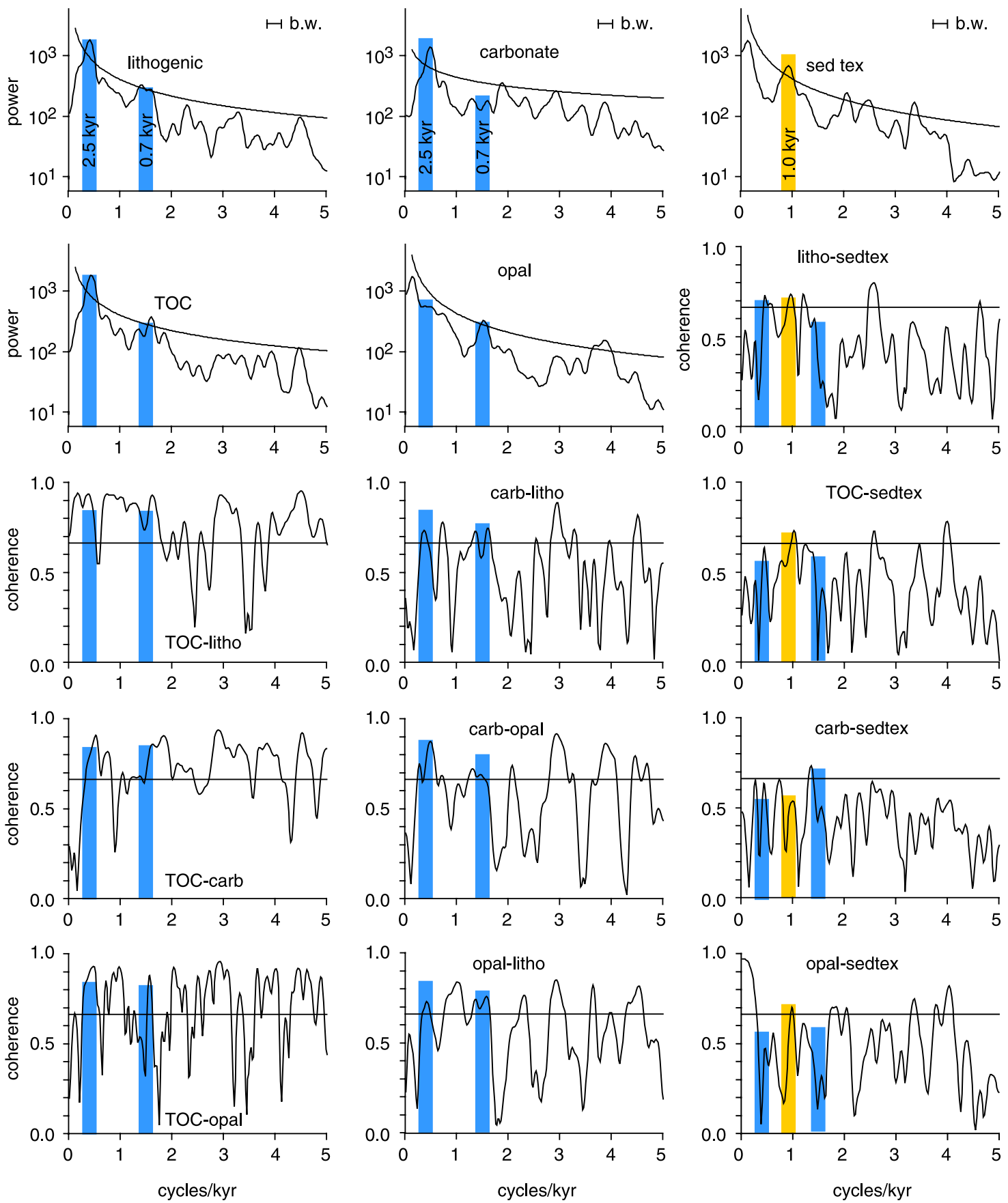

Figure 6. Blackman-Tukey power and coherence spectra for lithogenic and biogenic mass accumulation rates against each other and against sediment texture. Lines through power and coherence spectra represent 95\% confidence levels. Bars denote one bandwidth centered around significant frequencies in lithogenic accumulation rates (blue) and sediment texture (yellow). Abbreviations in coherence spectra are $\mathrm{carb}=$ carbonate, litho $=$ lithogenic, and sedtex $=$ sediment texture. Note that spectra are for Holocene data only.

in $G$. oceanica and $C$. leptoporus. Assemblage change at the end of the Younger Dryas is abrupt and occurs slightly before the change in sediment texture. A sudden increase in $E$. huxleyi and decrease in the relative abundance of $F$. profunda occurs between two samples at 18 and $9 \mathrm{~cm}$, or 45-90 years, below the shift from bioturbated Younger Dryas to laminated Holocene sediments (Figure 5).

[23] Within the Holocene there is modest variation in the assemblage composition (Figure 5). Fluctations in the abundance of E. huxleyi are mirrored by those in Geo- 

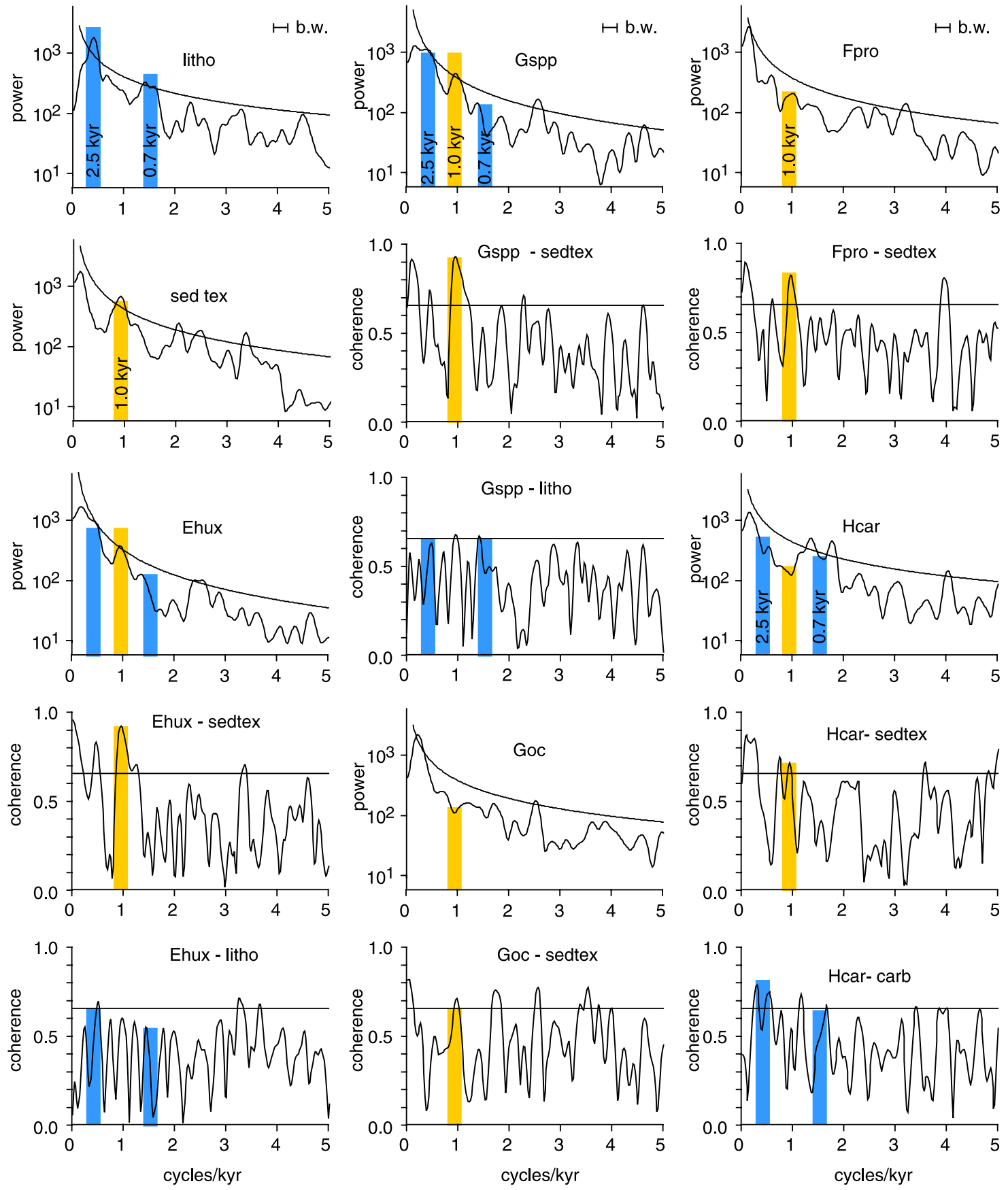

Figure 7. Blackman-Tukey power and coherence spectra for selected coccolithophorid species against lithogenic accumulation rates and sediment texture. Abbreviatons are Ehux $=E$. huxleyi, Gspp = Gephyrocapsa spp, Goc $=$ G. oceanica, Fpro $=F$. profunda, and Hcar $=H$. carteri. For further explanation see Figure 6.

phyrocapsa spp., which is at least partly do to a closed sum problem, as the two species together form between 60 and $90 \%$ of the Holocene assemblages. For the other species the main pattern is an increase in abundance of $F$. profunda, $H$. carteri, and $C$. leptoporus in the middle part of the Holocene ( $\sim 7000$ to $\sim 3000$ years BP) at the same time that $G$. oceanica and $C$. pelagicus show a decrease.
Umbilicosphaera sibogae, of which only sporadic specimens are present before $\sim 7000$ years BP, is more or less persistently present in the floras between $\sim 4000$ and $\sim 1000$ years BP.

\subsection{Cross-Spectral Analysis}

[24] Cross-spectral analysis is used to test if short-term fluctuations in the biogenic burial fluxes and coccolith 
abundance data correlate significantly with lithogenic sedimentation rates and/or sediment texture. Figure 6 shows power and coherence spectra for lithogenic and biogenic fluxes against each other and against sediment texture. Power spectra for lithogenic and TOC burial fluxes show significant peaks at $\sim 2.5 \mathrm{ka}$ and $\sim 700$ years. Only the $2.5 \mathrm{ka}$ peak is present in the spectrum for carbonate burial fluxes, while the $\sim 700$ years peak is significant in the power spectrum for opal burial fluxes. Still, all burial fluxes are strongly correlated at the $\sim 2.5 \mathrm{ka}$ and $\sim 700$ years frequencies. All coherence spectra for fluxes against each other show significant values around both frequencies. Especially the correlation of TOC with all other burial fluxes is very strong throughout most of the coherence spectra. The coherence between lithogenic, opal, and carbonate fluxes amongst each other is on average weaker (Figure 6).

[25] The sediment texture data show a significant $\sim 1000$ year cycle which is not significant in any of the burial flux data. In fact, the power spectra for all four burial fluxes show lower than average power in the $\sim 1000$ year frequency range (Figure 6). This means that any variation in this frequency range is very subdued and not distinguishable from any background noise. Still, lithogenic, TOC, and opal fluxes show significant coherence values with sediment texture in the $\sim 1000$ year frequency range. In addition, both opal burial rates and sediment texture show a long-term cycle or secular trend, which is strongly coherent. This secular trend reflects the long-term change in both opal burial and sediment texture with high values in the early and late Holocene but lower values in the middle part of the Holocene (Figures 3 and 4). The record is too short to determine if this trend is part of a consistent cycle or not.

[26] Representative coherence spectra for coccoliths against sediment texture and sediment burial rates within the Holocene are shown in Figure 7. Power spectra for both E. huxleyi and Geophyrocapsa spp. show a significant $\sim 1000$ year cycle and a secular trend, which are coherent with the corresponding cycles in sediment texture. Phase diagrams are not shown, but because the two species show opposing fluctuations (Figure 5), one is in phase with sediment texture (E. huxleyi) while the other is out of phase (Gephyrocapsa spp.). The $\sim 1000$ year cycle is weakly developed in the power spectrum of $F$. profunda, but it is not present in the spectra for any of the other species. However, most species show significant coherence values with sediment texture in the $\sim 1000$ year frequency band (Figure 7). Any correlation of coccolith assemblages with burial fluxes is much weaker than that with sediment texture. Some of the species show a subordinate peak or shoulder in their power spectrum in the $\sim 2.5 \mathrm{ka}$ frequency range, but the coherence with lithogenic burial fluxes in this range is not significant at the 95\% confidence level (e.g., Gephyrocapsa spp.) or only barely so (e.g., E. huxleyi). The correlation with carbonate burial rates is even weaker, and not significant for any of the species with one exception. Only H. carteri shows significant coherence with carbonate burial rates in the $\sim 2.5 \mathrm{ka}$ frequency range (Figure 7).

\section{Discussion}

\subsection{Millennial Cycles}

[27] There are two different millennial-scale cycles within the Holocene record at ODP Site 893, both of which correlate with the Greenland ice core records [Nederbragt and Thurow, 2005b]. The Santa Barbara Basin lamination index and GISP $2 \partial^{18} \mathrm{O}$ records both show a $\sim 1000$ year cycle, which is coherent with changes in the concentration of atmospheric

${ }^{14} \mathrm{C}$, and which was therefore attributed to solar forcing of especially high latitude climate. The other cycle in the Santa Barbara Basin is a $\sim 2750$ year cycle in sedimentation rates (varve thickness), which is coherent with fluctuation in aerosol concentrations in GISP2 [Nederbragt and Thurow, $2005 \mathrm{~b}]$. On the basis of the correlation between rainfall and varve thickness in the modern basin [Soutar and Crill, 1977] the $\sim 2750$ year cycle in the Holocene was interpreted as a rainfall cycle, which determines riverine fluxes and lithogenic sedimentation rates within the basin.

[28] Results here are similar, to the extent that we again find the same two cycles in two sets of paleoceanographic proxies, with little or no correlation between the two sets. The long cycle in lithogenic fluxes is here found to have a wavelength of $\sim 2.5 \mathrm{ka}$ (Figures 6 and 7 ) instead of 2750 years. This shift is due to the different spacing of the samples used in this study, and is not significant given the bandwidth of the power spectra (Figure 6); in the following text we will use the more general $\sim 2.5 \mathrm{ka}$ designation. In contrast, the coccolith assemblage data, which are sedimentation rate independent, show fluctuations that coincide with the sediment texture record. Large changes in assemblage composition occur across the MIS 2-Bölling/Allerød-Younger DryasHolocene transitions (Figure 5), while within the Holocene more subtle shifts are present in especially in the abundance of E. huxleyi and Geophyrocapsa spp., which are coherent with the 1000 year solar cycle in sediment texture (Figure 7; [Nederbragt and Thurow, 2005b]). Part of the coccolith species show significant coherence with the $\sim 2.5 \mathrm{ka}$ cycle in lithogenic sedimentation rates, but the power in this frequency range is low, which means that the $\sim 2.5 \mathrm{ka}$ cycle is a very minor component of the total coccolith assemblage variation. Similarly, biogenic burial fluxes show some indication of coherence with the 1000 year cycle, but without a significant amount of power in this frequency range. The fact that the 1000 and $\sim 2.5$ ka cycles are coherent with other paleoclimate records outside the Santa Barbara Basin [Nederbragt and Thurow, 2005b] implies that both the coccolith and sedimentation rate data for Site 893 represent some form of climate signal. However, the lack of correlation between the two implies that they are shaped by two independent paleoceanographic processes and that they are not both a measure for paleoproductivity, which is what they were measured for initially.

\subsection{Sediment Texture and Ventilation}

[29] The pattern of change between laminated and bioturbated sediments in the Santa Barbara Basin during the 
past $60 \mathrm{ka}$ is representative for paleoceanographic fluctuations in the wider region along the NE Pacific margin. Behl and Kennett [1996] recognized that laminated intervals between 25 to $60 \mathrm{ka} \mathrm{BP}$ at Site 893 are time-equivalent with interstadials as defined in the Greenland ice cores. Since then, Dansgaard/Oeschger cycles have been recognized in the last glacial along much of the California and Baja California margins [Cannariato and Kennett, 1999; Ortiz et al., 2004; Pisias et al., 2001], while the alternation across the Bölling/Allerød, Younger Dryas, and Holocene transitions can be recognized in shorter cores [e.g., Van Geen et al., 1996]. Outside the Santa Barbara Basin oxygen levels were usually not low enough to allow deposition of laminated sediments, but $\mathrm{D} / \mathrm{O}$ cycles are still expressed in pronounced fluctuations in the strength of the OMZ [ Van Geen et al., 1996]. It is still debated which paleoceanographic processes caused the observed changes in sediment composition. Various authors point to variation in intermediate water ventilation as the main control on the OMZ [Cannariato and Kennett, 1999; Van Geen et al., 1996] while others highlight the role of variation in surface water productivity [Ortiz et al., 2004; Pisias et al., 2001].

[30] The data we collected for the past 16,000 years in the Santa Barbara Basin support the conclusion that changes in intermediate water ventilation were the main control on oxygenation of the sediment-water interface. The link between observed organic carbon fluxes and paleoclimate will be discussed in section 5.3, but independent of the interpretation, the data show no indication for a positive correlation between organic carbon fluxes and dysoxia. In contrast, organic carbon fluxes were higher than average during the Younger Dryas and possibly during MIS 2, the two main intervals with better oxygenated conditions at the sea floor (Figures 3 and 4). Also within the Holocene there is no correlation between organic carbon fluxes and sediment texture (Figure 7). Overall, the lack of increase in carbon fluxes during periods of enhanced dysoxia in the Santa Barbara Basin indicates that low oxygen content in the subsurface in not due to increased oxygen demand. Therefore variation in degree of intermediate water ventilation is required to explain the changes in sediment texture.

\subsection{Coccolith Assemblages and Surface Water Conditions}

[31] Clear changes in coccolith assemblage data correspond to shifts between bioturbated and laminated sediments (Figure 5), supporting the conclusion of Cannariato and Kennett [1999] that ocean surface circulation changed more or less synchronously with intermediate water circulation. From the base of the Bölling/Allerød onward coccolith assemblages are diverse and show a consistent correlation with sediment texture. In general, bioturbated sediments (Younger Dryas and mid-Holocene) show increased abundance of stratification indicator $F$. profunda (Figure 5). In contrast, upwelling indicators G. oceanica and E. huxleyi are more abundant in laminated sediments. At the same time each interval has its own characteristics.

\subsubsection{Marine Isotope Stage 2}

[32] Samples from MIS 2 are distinct from the remainder of the section, with very low diversity assemblages domi- nated by Gephyrocapsa spp. Only cold water indicator $C$. pelagicus subsp pelagicus reaches values of persistently $\sim 1 \%$ amongst the rare species. Low carbonate content relative to opal (Figure 3) and low alkenone concentrations within glacial sediments [Herbert et al., 1995] indicate that carbonate production was low during MIS 2, and that cold water opal production was dominant until the start of the Bölling/Allerød.

\subsubsection{Younger Dryas and Mid-Holocene Bioturbated Intervals}

[33] The high abundance of $F$. profunda during the Younger Dryas and the mid-Holocene indicates that a substantial part of total annual coccolithophid production occurred during times of seasonal stratification and the development of a deep chlorophyll maximum [Molfino and McIntyre, 1990; Ziveri et al., 1995]. However, the overall assemblage in the Younger Dryas is most similar to that found in MIS 2 sediments, with common small Gephyrocapsa spp., rare G. oceanica and C. leptoporus, and higher than average abundance of cold water $C$. pelagicus subsp pelagicus (Figure 5). The assemblage composition is consistent with the modest cooling of the surface waters inferred from planktonic foraminiferal faunas and their $\delta^{18} \mathrm{O}$ composition [Hendy et al., 2002]. In contrast, abundant $F$. profunda during the mid-Holocene occurred during a period that sea surface temperatures reached a maximum, as indicated by minimum planktonic foraminiferal $\delta^{18} \mathrm{O}$ values [Kennett et al., 2000]. Within the coccolith assemblages, warm conditions are reflected in the near absence of cold water $C$. pelagicus subsp pelagicus. Maximum abundance of $H$. carteri and C. leptoporus (Figure 5), which correlate with high coccolith production [Broerse et al., 2000; Ziveri and Thunell, 2000; Ziveri et al., 1995], and maximum carbonate content relative to opal (Figure 3) suggest that warm conditions allowed high carbonate production.

\subsubsection{Coccolith Assemblages in Laminated Intervals}

[34] The predominantly laminated Bölling/Allerød, lower Holocene, and upper Holocene are marked by maximum abundance of either $G$. oceanica or E. huxleyi, two species that are linked with the upwelling season in the modern setting [De Bernardi et al., 2005; Ziveri et al., 1995]. Accurate interpretation of the assemblages within the Bölling/Allerød is difficult because of poor preservation. Part of the samples have the lowest carbonate content of the entire section (Figure 3), and the assemblages are dominated by robust species, including $G$. oceanica, relative to more fragile forms (Figure 5), which could be due to enhanced dissolution of fragile forms within a pronounced OMZ.

[35] Evidence for increased upwelling during the early and late Holocene is better constrained. The sharp increase in E. huxleyi at the base of the Holocene suggests that conditions similar to the modern upwelling system were established at the onset of the Holocene. A simultaneous increase in upwelling indicators is also seen in planktonic foraminifera at Site 893 [Hendy et al., 2002], and, north of the Santa Barbara Basin, in upwelling related radiolaria [Pisias et al., 2001] and in alder and redwood pollen. The last indicates expansion of the coastal redwood forests which are dependent on fog produced during the summer upwelling season [Barron et al., 2003; Pisias et al., 2001]. 
The distribution of $U$. sibogae is significant as it is indicative for warm and fully oligotrophic conditions [Okada and McIntyre, 1977]. This variety, which is absent in the middle Holocene, occurs sporadically in lower Holocene samples but is consistently present in the upper Holocene (Figure 5). In the modern setting influxes of warm, oligotrophic planktonic species occur during El Niño conditions in response to exceptional warming of the surface waters [De Bernardi et al., 2005; Lange et al., 2000]. The distribution of $U$. sibogae therefore suggests that El Niño events as expressed in the modern Santa Barbara Basin occurred sporadically during the early Holocene, were absent during the middle Holocene, and reached their modern frequency and/or intensity around 4 ka BP (Figure 5). North of the Santa Barbara Basin similar maxima in the lower and upper Holocene are found for the gyre-diatom Pseudoeunotia doliolus [Barron et al., 2003] and subtropical radiolaria [Pisias et al., 2001], indicating that the long-term variation in surface water circulation within the Holocene was coherent along the California margin.

\subsubsection{Millennial Cycles During the Holocene}

[36] The $\sim 1 \mathrm{ka}$ fluctuations in coccolith assemblages and sediment texture during the Holocene (Figure 7) are more difficult to relate to specific changes in surface water conditions. The $\sim 1$ ka cycle is significant only in $E$. huxleyi relative to small Gephyrocapsa spp. Both forms have a ubiquitous distribution and the difference in ecological preferences is not well enough understood to allow a interpretation of specific changes in surface conditions. In all other species, the $\sim 1 \mathrm{ka}$ is within the noise, even though coherent with sediment texture (Figure 7). We therefore conclude that the $\sim 1$ ka solar cycle had a weak (unspecified) impact on surface water conditions in the Santa Barbara Basin but is predominantly related to ventilation at intermediate depth as reflected in sediment texture.

\subsection{Organic Carbon Burial}

\subsubsection{Reliability of Flux Estimates}

[37] The burial rates we measured for the Holocene (Figure 4) are within the range of modern flux estimates obtained from sediment trap data collected for the period 1993-1996 in the Santa Barbara Basin [Thunell, 1998a]. Average Holocene total mass and carbonate accumulation rates (790 and $75 \mathrm{~g} / \mathrm{m}^{2} / \mathrm{a}$ respectively; Figure 4) are very similar to the sediment trap values $\left(714\right.$ and $\left.56 \mathrm{~g} / \mathrm{m}^{2} / \mathrm{a}\right)$. Organic carbon fluxes in the sediment traps were higher $\left(32 \mathrm{~g} / \mathrm{m}^{2} / \mathrm{a}\right)$ than in the sediment $\left(16 \mathrm{~g} / \mathrm{m}^{2} / \mathrm{a}\right)$, which can be explained by further degradation of organic matter within the sediment. The only substantial difference is found in opal flux estimates. The opal values for the sediment traps (129 g/m²/a [Thunell, 1998a]) are $\sim 2.5$ times higher than the average we measured for the Holocene $\left(54 \mathrm{~g} / \mathrm{m}^{2} / \mathrm{a}\right.$; Figure 4). Low opal content within the sediment could be partly due to dissolution of opal at the sea floor and/or within the sediment [Broecker and Peng, 1982]. In addition, there may have been differences in the protocol used to measure biogenic silica content. Although the method of Mortlock and Froelich [1989] was used in both cases [Nederbragt et al., 2006; Thunell, 1998a], results are strongly dependent on the temperature at which opal is dissolved and the duration of the reaction. How important this factor is cannot be evaluated as the exact protocol used to measure the sediment trap samples was not specified [Thunell, 1998a]. Finally, the difference in average Holocene and modern opal fluxes could be real and due to high diatom productivity during the duration of the sediment trap experiment. However, the overall similarity with the sediment trap data indicates that the Holocene burial rates measured here are representative for marine fluxes settling through the water column.

[38] As far as organic carbon burial rates are concerned the result here is a time series that is essentially unrelated to fluctuations in surface and intermediate water conditions as expressed in changes in coccolith assemblages and sediment texture. The main feature is a correlation with sedimentation rates, to the extent that any short-term fluctuations in TOC burial rates are mirrored by similar changes in lithogenic fluxes (Figures 4 and 6). The fact that the $\sim 2.5 \mathrm{ka}$ cycle in sedimentation rates correlates with Holocene dust concentrations in the GISP2 [Nederbragt and Thurow, 2005b] suggests that the pattern represents an underlying climate signal and that interpolation of sedimentation rates across bioturbated intervals did not introduce any major errors. However, the actual pattern of variation is not critical for the purpose of this paper, only that organic carbon burial rates correlate with lithogenic sediment accumulation rates and not with surface or intermediate water conditions. This correlation is confirmed by the subset of varved samples, for which the sedimentation rates could be reconstructed unambiguously through measurement of annual layer thickness (Figure 4). Any errors in the dry bulk density estimates due to sampling after long storage are not large enough to have influenced results significantly. Opal and TOC content, the two components that have a strong influence on sediment density [Gardner et al. 1997], are relatively uniformly distributed. This implies that the overall gradual trend in dry bulk density (Figure 2) is real and reflects lack of variation in sediment composition. We therefore conclude that there is an intrinsic relation between carbon burial and bulk sedimentation rates, which is due to modification of the original productivity signal by secondary processes in the water column and/or in the sediment. The main processes that are recognized to modify rain and/or burial rates of organic matter are oxygen content in the subsurface ocean, exposure time at the sea floor as a function of sedimentation rates, and the presence of ballast minerals in the water column.

\subsubsection{Oxygenation}

[39] The idea that anoxic environments promote the preservation of organic matter goes back to observation of high TOC content in sediments in the Black Sea [Woolnough, 1937]. The euxinic conditions in the Black Sea have long been used as an analog for black shale deposits in the geologic record. However, the role of high productivity in the surface water is being emphasized increasingly as the main factor controlling the deposition of ancient organic rich deposits [Calvert, 1987; Kuypers et al., 2002; Nederbragt et $a l ., 2004]$. Whether lack of oxygen at the sea floor has any immediate effect on carbon preservation remains debated. Killops and Killops [2004] suggest that rates of anaerobic and aerobic degradation are probably very similar, and that anaerobic degradation only seems slow because it often acts on organic matter that is already partly degraded and there- 
fore more resistant to further degradation. The role of oxygen in the modern ocean is difficult to isolate from other factors. For example, Devol and Hartnett [2001] concluded that the rate of degradation of organic matter in the water column is lower under dysoxic conditions. However, this conclusion is at least partly based on observation of low carbon burial rates on the shelf off northwest Mexico. Yet in another study in the same area it was found that organic matter on the shelf is poorly preserved, and low rates of TOC burial were attributed to selective removal of fine grained organic matter due to winnowing [Ganeshram et al., 1999]. Further offshore in the same region there is no difference in preservation between organic matter on the slope within the OMZ and that in the deep ocean under oxic conditions [Ganeshram et al., 1999]. Similarly, no change in preservation was found between organic matter reaching the sea floor in the deep Pacific compared to that settling through the OMZ under the upwelling area in the Arabian Sea [Hedges et al., 2001]. Oxygen levels in the water column within Santa Barbara Basin also seem to have been of little importance for the rate of organic carbon burial. Because of the lack of correlation between burial rates and degree of lamination, higher than average rates of organic carbon burial occur in homogeneous as well as in laminated intervals (Figure 4). Any effect of fluctuations in redox conditions on TOC preservation are apparently completely overshadowed by the correlation between TOC and lithogenic burial rates.

\subsubsection{Sedimentation Rates, Ballast Minerals, and Biological Mediation}

[40] The main process that determined carbon burial in the Santa Barbara Basin appears to be the interaction of carbon export from the surface water with the amount of suspended lithogenic material. The existence of a strong correlation between organic carbon and bulk sediment fluxes has been noted in numerous studies, both within the water column in sediment traps [Armstrong et al., 2002; Francois et al., 2002; Ittekkot, 1993; Klaas and Archer, 2002; Thunell, 1998a; Thunell, 1998b] and at the sea floor [Hedges and Keil, 1995; Müller and Suess, 1979]. Within the water column, the presence of ballast minerals increases the export efficiency either by increasing the weight and thus sinking speed and effectiveness of faecal pellets and marine snow or by offering some form of protection against degradation through adsorption onto fine particles. In the open ocean, carbonate in the form of coccoliths is the main ballast mineral [Armstrong et al., 2002; Francois et al., 2002; Klaas and Archer, 2002]. Klaas and Archer [2002] estimated that 83 percent of organic carbon export is associated with carbonate. However, this estimate does not include carbon burial near continental margins, which is quantitatively as important as that in the open ocean [Muller-Karger et al., 2005] or even more so [Hedges and Keil, 1995]. Near-shore, lithogenic material appears to play a more important role as ballast mineral [Ittekkot, 1993]. Indeed, in sediment traps from the Santa Barbara Basin and the Gulf of California carbon fluxes correlate most strongly with total mass fluxes, with linear correlation coefficients of $\mathrm{r}=0.83$ and $\mathrm{r}=0.82$ respectively [Thunell, 1998a; Thunell, 1998b]. As in our data (Figures 4 and 6), the correlation with carbonate fluxes is less pronounced, possibly because carbonate fluxes form a relatively small part of the total flux in these opal rich environments. A further factor may be that planktonic foraminifera make up a larger portion of the pelagic carbonate production during the high-productivity season in both basins [De Bernardi et al., 2005; Ziveri and Thunell, 2000]. Planktonic foraminiferal tests usually sink to the ocean floor on their own rather than in faecal pellets like coccoliths, which suggests that they do not play a role as ballast mineral [Passow et al., 2001].

[41] On the sea floor, high accumulation rates reduce the exposure time of organic matter to oxygen [Müller and Suess, 1979]. The most generally accepted explanation for the presence of a strong correlation between organic carbon and total mass accumulation rates [Müller and Suess, 1979] is that rates of carbon degradation slow down within the sediment, because of slow diffusion of electron acceptors [Hedges and Keil, 1995]. It is in this context that the presence of oxygen in the water column should make a difference in preservation of organic matter. Large bioturbating organisms, which can aereate the sediment down to a depth of $0.5 \mathrm{~m}$, are by definition absent under anoxic or severely dysoxic conditions. All else being equal, bioturbation in the presence of oxic bottom water will increase the oxygen exposure time, which should therefore decrease the preservation potential of organic matter. However, low oxygen conditions in the modern ocean usually occur along continental margins where both marine productivity and bulk sedimentation rates are high, apparently making it difficult to quantify the contribution of the various processes relative to each other.

[42] There is another mechanism that could explain the tight correlation between carbon and lithogenic fluxes, which is that biological mediation enhances sedimentation of suspended sediment [Deuser et al., 1983; Passow and De la Rocha, 2006; Thunell et al., 1995]. Clay particles can remain in suspension in the water column for long periods of time if there is no biological activity to aid flocculation. Passow and De la Rocha [2006] suggested that the flux of organic carbon in the water column actually controls bulk sediment fluxes through biological mediation rather than the inverse, that ballast minerals control carbon export. Biological mediation has indeed been inferred to contribute to sedimentation in the Santa Barbara Basin [Thunell et al., 1995]. Maximum rainfall and river runoff around the Santa Barbara Basin occur in winter. Yet there is a second increase in lithogenic fluxes during the upwelling season in spring, when riverine fluxes are low, which was attributed to biological mediation of suspended material [Thunell, 1998a]. A similar pattern is seen in Saanich Inlet, an anoxic fjord off Vancouver Island in western Canada. Concentrations of both nutrients and suspended sediment are high in the surface waters of the inlet during winter, when maximum river discharge occurs; however, marine productivity remains low because of light limitation [Takahashi et al., 1978]. Sediment trap data for the center of the inlet showed that total fluxes to the sea floor were low in winter, but doubled at the start of the spring bloom, when biological activity increased [Sancetta and Calvert, 1988]. Yet biogenic material, consisting mainly of diatoms, forms only $25-35 \%$ of the total sediment on the sea floor [Gucluer and Gross, 1964], indicating that lithogenic sedimentation rates are high in spring and summer when river 
discharge is at a minimum. Analysis of the composition of fossil varves in Saanich Inlet confirms this pattern, in that the spring-summer laminae are usually 3 to 5 times thicker than adjacent winter laminae [Dean et al., 2001]. The increase in lithogenic sediment fluxes during the marine productivity season in both the Santa Barbara Basin and Saanich Inlet indicate that biological mediation is indeed important for lithogenic sedimentation.

[43] The relative importance of ballast minerals driving TOC fluxes versus biological mediation controlling sedimentation rates can be evaluated from recent sediments in the Santa Barbara Basin. Soutar and Crill [1977] showed that varve thickness, or annual accumulation rate, correlates significantly with annual rainfall in California for the period $1868-1966$. There is a pronounced $\sim 25$ year cycle in both rainfall and varve thickness, which correlates with the Pacific Decadal Oscillation [Nederbragt and Thurow, 2005a]. However, cross-spectral analysis of the varve thickness time series of Soutar and Crill [1977] against the Southern Oscillation Index indicates that high-frequency variability in sedimentation rates is related to ENSO cycles, not to interannual variability in rainfall [Nederbragt and Thurow, 2005a]. The authors concluded that the high-frequency component is modulated by marine productivity, but that rainfall and riverine fluxes control the long-term trend in sedimentation rates, through determining the availability of sediment within the basin. The amount of variability associated with the 25 year rainfall cycle accounts for $>60 \%$ of the total variation in the varve thickness time series of Soutar and Crill [1977], suggesting that sediment supply limits the amount of suspended material that can be biologically mediated. The strong correlation between organic carbon and lithogenic accumulation rates throughout the last $16 \mathrm{ka}$ (Figures 4 and 6) therefore indicates that riverine runoff is ultimately the dominant control on long-term variation in organic carbon burial rates in the Santa Barbara Basin.

\section{Conclusions}

[44] Sediments deposited at ODP Site 893 since $16 \mathrm{ka} \mathrm{BP}$ show cyclic alternation between laminated and bioturbated intervals. However, there is no correlation between organic carbon burial rates and the degree of lamination. High rates of organic carbon burial are found in intervals that represent better oxygenated conditions (e.g., the Younger Dryas) as well as in distinctly laminated intervals which are indicative for pronounced dysoxia. The result implies that oxygen levels at the sea floor are controlled mainly by variation in intermediate water ventilation, and not by surface water productivity. The lack of correlation between organic carbon content and sediment texture also indicates that varia- tion in oxygen levels at the sea floor had little or no impact on the preservation potential of organic carbon.

[45] Coccolith abundance data correlate significantly with variation in sediment texture, indicating that surface water circulation and subsurface ventilation changed in concert. However, it remains unclear whether changes in surface conditions were associated with a change in average annual productivity. Overall, productivity shifted gradually from cold water, opal dominated productivity during the last glacial to increased carbonate production during especially the middle Holocene. Millennial cycles are superimposed on the long-term trend. High abundance of F. profunda in homogeneous sediments deposited during the Younger Dryas and the middle Holocene suggest that a large part of the coccolithophorid production occurred during extended periods of thermal stratification. In contrast, predominantly laminated intervals (Bölling/Allerød, lower and upper Holocene) are characterized by increased abundances of upwelling-associated species (G. oceanica and/or $E$. huxleyi). Within the Holocene, there is a coherent $\sim 1 \mathrm{ka}$ solar cycle in both sediment texture and coccolith data, but changes in the coccolith assemblages at this scale are subtle and cannot be related to specific conditions.

[46] Organic carbon burial rates in the Santa Barbara Basin correlated strongly with lithogenic accumulation rates throughout the past $16 \mathrm{ka}$, and to a lesser extent with carbonate and opal burial rates. In contrast, organic carbon burial rates varied independently of surface water conditions as inferred from coccolith assemblages. The variation in organic carbon fluxes is therefore attributed to variation in export efficiency from the sea surface due to lithogenic material acting as a ballast mineral, which increases the sinking speed of faecal pellets and marine snow and/or protects the organic carbon from degradation through adsorption onto fine particles. The existence of a strong correlation between sediment accumulation rates in the modern Santa Barbara Basin and rainfall on the continent indicates that past variations in organic carbon export in the basin are largely the result of variation in riverine fluxes, and not of variation in marine productivity. The result implies that anthropogenic changes in riverine sediment transport due to damming of rivers and/or changes in land use contribute to perturbation of the global carbon cycle through modification of carbon export efficiency in the marine realm.

[47] Acknowledgments. We thank G. Dickens, A. Schimmelmann, and an anonymous reviewer for helpful suggestions to improve the manuscript. This research used samples provided by the Ocean Drilling Program (ODP). ODP is sponsored by the U.S. National Science Foundation (NSF) and participating countries under management of Joint Oceanographic Institutions (JOI), Incorporated. Support for this research was provided by NERC (UK) grant NER/T/S/2000/01343.

\section{References}

Armstrong, R. A., C. Lee, J. I. Hedges, S. Honjo, and S. G. Wakeham (2002), A new, mechanistic model for organic carbon fluxes in the ocean based on the quantitative association of POC with ballast minerals, Deep Sea Res., Part II, 49, 219-236.
Barron, J. A., L. Heusser, T. Herbert, and M. Lyle (2003), High-resolution climatic evolution of coastal northern California during the past 16,000 years, Paleoceanography, 18(1), 1020, doi:10.1029/2002PA000768.
Behl, R. J., and J. P. Kennett (1996), Brief interstadial events in the Santa Barbara Basin, NE Pacific, during the past $60 \mathrm{kyr}$, Nature, 379, 243-246.

Berner, R. A., and R. Raiswell (1983), Burial of organic carbon and pyrite sulfur in sediments 
over Phanerozoic time; a new theory, Geochim. Cosmochim. Acta, 47, 855-862.

Biondi, F., C. B. Lange, M. K. Hughes, and W. H. Berger (1997), Inter-decadal signals during the last millenium (AD 1117-1992) in the varve record of Santa Barbara Basin, California, Geophys. Res. Lett., 24, 193-196.

Broecker, W. S. (1982), Glacial to interglacial changes in ocean chemistry, Progress Oceanogr., 11, 151-197.

Broecker, W. S. and T.-H. Peng (1982), Tracers in the Sea, 690 pp., Eldigio Press, Palisades, N. Y.

Broerse, A. T. C., G. J. A. Brummer, and J. E. Van Hinte (2000), Coccolithophore export production in response to monsoonal upwelling off Somalia (northwestern Indian Ocean), Deep Sea Res., Part II, 47, 2179-2205.

Calvert, S. E. (1987), Oceanographic controls on the accumulation of organic matter in marine sediments, Geol. Soc. London Spec. Publ., 26, $137-151$.

Cannariato, K. G., and J. P. Kennett (1999), Climatically related millennial-scale fluctuations in strength of California margin oxygen-minimum zone during the past 60 k.y, Geology, 27, 975-978.

Dean, J. M., A. E. S. Kemp, and R. B. Pearce (2001), Palaeo-flux records from electron microscope studies of Late Holocene laminated sediments, Saanich Inlet, British Columbia, Mar. Geol., 174, 139-158.

De Bernardi, B., P. Ziveri, E. Erba, and R. C. Thunell (2005), Coccolithophore export production during the 1997-1998 El Niño event in Santa Barbara Basin (California), Mar. Micropaleontol., 55, 107-125.

Deuser, W., P. Brewer, T. Jickells, and R. Commeau (1983), Biological control of the removal of abiogenic particles from the surface of the ocean, Science, 219, 388-391.

Devol, A. H., and H. E. Hartnett (2001), Role of the oxygen-deficient zone in transfer of organic carbon to the deep ocean, Limnol. Oceanogr., 46, 1684-1690.

Filippelli, G. M., and M. L. Delaney (1996), Phosphorus geochemistry of equatorial Pacific sediments, Geochim. Cosmochim. Acta, 60, 1479-1495.

Fleischner, P. (1972), Mineralogy and sediment history, Santa Barbara Basin, California, J. Sed. Petrol., 42, 49-58.

Francois, R., S. Honjo, R. Krishfield, and S. Manganini (2002), Factors controlling the flux of organic carbon to the bathypelagic zone of the ocean, Global Biogeochem. Cycles, 16(4), 1087, doi:10.1029/2001GB001722.

Ganeshram, R. S., S. E. Calvert, T. F. Pedersen, and G. L. Cowie (1999), Factors controlling the burial of organic carbon in laminated and bioturbated sediments off NW Mexico: Implications for hydrocarbon preservation, Geochim. Cosmochim. Acta, 63, 1723-1734.

Ganeshram, R. S., T. F. Pedersen, S. E. Calvert, G. W. McNeill, and M. R. Fontugne (2000), Glacial-interglacial variability in denitrification in the world's oceans: Causes and consequences, Paleoceanography, 15, 361-376.

Gardner, J. V., W. E. Dean, and P. Dartnell (1997), Biogenic sedimentation beneath the California Current system for the past $30 \mathrm{kyr}$ and it paleoceanographic significance, Paleoceanography, 12, 207-225.

Geisen, M., C. Billard, A. T. C. Broerse, L. Cros, I. Probert, and J. R. Young (2002), Life-cycle associations involving pairs of holococcolithophorid species: Intraspecific variation or cryptic speciation?, Eur. J. Phycol., 37, 531-550.
Gorsline, D. S., R. L. Kolpack, H. A. Karl, D. E. Drake, P. Fleischer, S. E. Thornton, J. R. Schwalzbach, and C. E. Savdra (1984), Studies of fine-grained sediment transport processes and products in the California continental borderland, Geol. Soc. London Spec. Publ., 15, $395-415$.

Gucluer, S. M., and M. G. Gross (1964), Recent marine sediments in Saanich Inlet, a stagnant marine basin, Limnol. Oceanogr., 9, 359-376.

Harms, S., and C. D. Winant (1998), Characteristic patterns of the circulation in the Santa Barbara Channel, J. Geophys. Res., 103, 3041-3065

Hedges, J. I., and R. G. Keil (1995), Sedimentary organic matter preservation; an assessment and speculative synthesis, Mar. Chem. $49,81-115$.

Hedges, J. I., J. A. Baldock, Y. Gelinas, C. Lee, M. Peterson, and S. G. Wakeham (2001), Evidence for non-selective preservation of organic matter in sinking marine particles, Nature, 409, $801-804$.

Hendy, I. L., and J. P. Kennett (1999), Latest Quaternary North Pacific surface-water responses imply atmosphere-driven climate instability, Geology, 27, 291-294.

Hendy, I. L., J. P. Kennett, E. B. Roark, and B. L. Ingram (2002), Apparent synchroneity of submillennial scale climate events between Greenland and Santa Barbara Basin, California from 30-10 ka, Quat. Sci. Rev., 21, 1167-1184.

Herbert, T. D., M. Yasuda, and C. Burnett (1995), Glacial-interglacial sea-surface temperature record inferred from alkenone unsaturation indices, Site 893, Santa Barbara Basin, Proc. Ocean Drill. Program Sci. Results, 146 , 257-264.

Hickey, B. M. (1998), Coastal oceanography of western North America from the tip of Baja California to Vancouver Island, in The Sea, edited by K. H. Brink, pp. 345-391, John Wiley, New York.

Ittekkot, V. (1993), The abiotically driven biological pump in the ocean and short-term fluctuations in atmospheric $\mathrm{CO}_{2}$ contents, Global Planet. Change, 8, 17-25.

Kennett, J. P., et al. (1994), Proceedings of the Ocean Drilling Program, Initial Reports, vol. 146(2), 1048 pp., Ocean Drill. Program, College Station, Tex.

Kennett, J. P., K. G. Cannariato, I. L. Hendy, and R. J. Behl (2000), Carbon isotopic evidence for methane hydrate instability during Quaternary interstadials, Science, 288, 128-133.

Killops, S. and V. Killops (2004), Introduction to Organic Geochemistry, 393 pp., Blackwell Publ. Oxford.

Klaas, C., and D. E. Archer (2002), Association of sinking organic matter with various types of mineral ballast in the deep sea: Implications for the rain ratio, Global Biogeochem. Cycles, 16(4), 1116, doi:10.1029/2001GB001765.

Kuypers, M. M. M., R. D. Pancost, I. A. Nijenhuis, and J. S. Sinninghe Damsté (2002), Enhanced productivity led to increased organic carbon burial in the euxinic North Atlantic basin during the late Cenomanian oceanic anoxic event Paleoceanography, 17(4), 1051, doi:10.1029/ 2000PA000569.

Lange, C. B., A. L. Weinheimer, F. M. H. Reid, E. Tappa, and R. C. Thunell (2000), Response of siliceous microplankton from the Santa Barbara Basin to the 1997-98 El Niño event, Calif. Coop. Oceanic Fish. Invest. Rep., 41, 186-193.

McCave, I. N. (1975), Vertical flux of particles in ocean, Deep Sea Res., 22, 491-502.
McIntyre, A., A. W. H. Bé, and M. B. Roche (1970), Modern Pacific coccolithophorida: A paleontological thermometer, Trans. N. Y. Acad. Sci., 32, 720-731.

Molfino, B., and A. McIntyre (1990), Nutricline variation in the equatorial Atlantic coinciden with the Younger Dryas, Paleoceanography, 5 , 997-1008

Mortlock, R. A., and P. N. Froelich (1989), A simple method for the rapid determination of biogenic opal in pelagic marine sediments, Deep Sea Res., Part A, 36, 1415-1426.

Müller, P. J., and E. Suess (1979), Productivity, sedimentation-rate, and sedimentary organic-matter in the oceans: 1. Organic-carbon preservation, Deep Sea Res., Part A, 26, $1347-1362$.

Muller-Karger, F. E., R. Varela, R. Thunell, R. Luerssen, C. Hu, and J. J. Walsh (2005), The importance of continental margins in the global carbon cycle, Geophys. Res. Lett., 32, L01602, doi:10.1029/2004GL021346.

Narciso, A., M. Cachao, and L. De Abreu (2006), Coccolithus pelagicus subsp. pelagicus versus Coccolithus pelagicus subsp. braarudii (Coccolithophore, Haptophyta): A proxy for surface subarctic Atlantic waters off Iberia during the last $200 \mathrm{kyr}$, Mar. Micropaleontol. $59,15-34$

Nederbragt, A. J., and J. Thurow (2005a), Amplitude of ENSO cycles in the Santa Barbara Basin, off California, during the past 15000 years, J. Quat. Sci., 20, 447-456.

Nederbragt, A. J., and J. Thurow (2005b), Geographic coherence of millennial-scale climate cycles during the Holocene, Palaeogeogr Palaeoclimatol. Palaeoecol., 221, 313-324.

Nederbragt, A. J., J. Thurow, H. Vonhof, and H.-J. Brumsack (2004), Modelling oceanic carbon and phosphorus fluxes: Implications for the cause of the late Cenomanian Oceanic Anoxic Event (OAE2), J. Geol. Soc., 161, 721-728.

Nederbragt, A. J., R. B. Dunbar, A. T. Osborn, A. Palmer, J. Thurow, and T. Wagner (2006), Sediment colour analysis from digital images and correlation with sediment composition, Geol. Soc. London Spec. Publ., 267, 113-128.

Okada, H., and A. McIntyre (1977), Modern coccolithophores of the Pacific and North Atlantic oceans, Micropaleontology, 23, 1-54.

Okada, H., and A. McIntyre (1979), Seasonal distribution of modern coccolithophores in the western North Atlantic Ocean, Mar. Biol. 54, 319-328.

Ortiz, J. D., S. B. O’Connell, J. DelViscio, W. Dean, J. D. Carriquiry, T. Marchitto, Y. Zheng, and A. van Geen (2004), Enhanced marine productivity off western North America during warm climate intervals of the past 52 k.y, Geology, 32, 521-524.

Paillard, D., L. Labeyrie, and P. Yiou (1996), Macintosh program performs time-series analysis, EOS Trans. $A G U, 77,379$

Passow, U., and C. L. De la Rocha (2006) Accumulation of mineral ballast on organic aggregates, Global Biogeochem. Cycles, 20 GB1013, doi:10.1029/2005GB002579.

Passow, U., R. F. Shipe, A. Murray, D. K. Pak M. A. Brzezinski, and A. L. Alldredge (2001), The origin of transparent exopolymer particles (TEP) and their role in the sedimentation of particulate matter, Cont. Shelf Res, 21, 327-346.

Pisias, N. G., A. C. Mix, and L. Heusser (2001), Millennial scale climate variability of the northeast Pacific Ocean and northwest North America based on radiolaria and pollen, Quat. Sci. Rev., 20, 1561-1576. 
Reimers, C. E., C. B. Lange, M. Tabak, and J. M. Bernhard (1990), Seasonal spillover and varve formation in the Santa Barbara Basin, California, Limnol. Oceanogr., 35, 1577-1585.

Sancetta, C., and S. E. Calvert (1988), The annual cycle of sedimentation in Saanich Inlet, British Columbia: Implications for the interpretation of diatom fossil assemblages, Deep Sea Res., 35, $71-90$.

Schimmelmann, A., and M. Kastner (1993), Evolutionary changes over the last 1000 years of reduced sulfur phases and organic carbon in varved sediments of the Santa Barbara Basin, California, Geochim. Cosmochim. Acta, 57, $67-78$.

Sigman, D. M., and E. A. Boyle (2000), Glacial/ interglacial variations in atmospheric carbon dioxide, Nature, 407, 859-869.

Soutar, A., and P. A. Crill (1977), Sedimentation and climatic patterns in the Santa Barbara Basin during the 19th and 20th centuries, Geol. Soc. Am. Bull., 88, 1161-1172.

Takahashi, M., J. Barwell-Clarke, F. Whitney, and P. Koeller (1978), Winter condition of marine plankton populations in Saanich Inlet, B.C., Canada. I. Phytoplankton and its sur- rounding environment, J. Exp. Mar. Biol. Ecol., 31, 283-301.

Talley, L. D. (1993), Distribution and Formation of North Pacific Intermediate Water, J. Phys. Oceanogr., 23, 517-537.

Thornton, S. E. (1984), Basin model for the hemipelagic sedimentation in a tectonically active continental margin: Santa Barbara Basin, California continental borderland, Geol. Soc. London Spec. Publ., 15, 377-394.

Thunell, R. C. (1998a), Particle fluxes in a coastal upwelling zone: Sediment trap results from Santa Barbara Basin, California, Deep Sea Res., Part I, 45, 1863-1884.

Thunell, R. C. (1998b), Seasonal and annual variability in particle fluxes in the Gulf of $\mathrm{Ca}$ lifornia; a response to climate forcing, Deep Sea Res., Part I, 45, 2059-2083.

Thunell, R. C., E. Tappa, and D. M. Anderson (1995), Sediment fluxes and varve formation in Santa Barbara Basin, offshore California, Geology, 23, 1083-1086.

Van Geen, A., R. G. Fairbanks, P. Dartnell, M. McGann, J. V. Gardner, and M. Kashgarian (1996), Ventilation changes in the northeast Pacific during the last deglaciation, Paleocea nography, 11, 519-528.
Woolnough, W. G. (1937), Sedimentation in barred basins, and source rocks of oil, Am Assoc. Petrol. Geol. Bull, 21, 1101-1157.

Young, J., M. Geisen, L. Cros, A. Kleine, C. Sprengel, I. Probert, and J. Østergaard (2003), A guide to extant coccolithophore taxonomy, J. Nannoplankton Res., Spec. Issue, 1 , $1-125$.

Ziveri, P., and R. C. Thunell (2000), Coccolithophore export production in Guaymas Basin, Gulf of California: Response to climate forcing, Deep Sea Res., Part I, 47, 2073 2100

Ziveri, P., R. C. Thunell, and D. Rio (1995), Export production of coccolithophores in an upwelling region: Results from San Pedro $\mathrm{Ba}$ sin, southern California borderlands, Mar. Micropaleontol., 24, 335-358.

P. R. Bown, A. J. Nederbragt, and J. W. Thurow, Department of Earth Sciences, University College London, Gower Street, London WC1E 6BT, UK. (a.nederbragt@ucl.ac.uk) 